\title{
Reconfiguring Boundaries and Norms in Qing- Chosŏn Relations: A Review Essay
}

\author{
MASATO HASEGAWA 長谷川正人 \\ National Taiwan University
}

Kim, Seonmin. Ginseng and Borderland: Territorial Boundaries and Political Relations between Qing China and Chosŏn Korea, 1636-1912. Oakland, CA: University of California Press, 2017. (Also available as an open access ebook at https://doi.org/10.1525/luminos.36)

Song, Nianshen. Making Borders in Modern East Asia: The Tumen River Demarcation, 1881-1919. Cambridge: Cambridge University Press, 2018.

Wang, Yuanchong. Remaking the Chinese Empire: Manchu-Korean Relations, 1616-1911. Ithaca, NY: Cornell University Press, 2018.

"Korea was the model tributary," wrote Hae-jong Chun in his contribution to John King Fairbank's seminal collection of essays on Qing foreign policy published in 1968. "During the Ch'ing era official Sino-Korean relations, mainly concerned with the sending and receiving of embassies and the conduct of trade between the two countries, provided an example of the relations expected or desired between China and other peripheral states." Such an image of the Chosŏn in the Qing period has long influenced the manner in which we have approached and interpreted the tributary relationship between the Qing and the Chosŏn. To complicate matters further, Sino-Korean relations during the Ming period have also often been characterized in a similar manner, ${ }^{2}$ and the fact that the Chosŏn dynasty as a political institution survived beyond the Ming-Qing transition in China has led scholars to infer a certain continuity in Sino-Korean relations throughout the Ming-Qing period. In examining the asymmetrical nature of SinoKorean relations in the Ming-Qing period, recent studies have foregrounded the agency of the Chosŏn court. ${ }^{3}$ But many questions still remain as to what Korea's geographical, political, and cultural proximity to China actually meant in the Ming-Qing period and

1. Hae-jong Chun, "Sino-Korean Tributary Relations in the Ch'ing Period," in The Chinese World Order: Traditional China's Foreign Relations, ed. John King Fairbank (Cambridge, MA: Harvard University Press, 1968), 90.

2. See, for example, Donald N. Clark, "Sino-Korean Tributary Relations under the Ming," in The Cambridge History of China, vol. 8, The Ming Dynasty, 1368-1644, Part 2, ed. Denis Twitchett and Frederick W. Mote (New York: Cambridge University Press, 1998), 273.

3. For a recent reference to Chosŏn agency, see Odd Arne Westad, Empire and Righteous Nation: 600 Years of China-Korea Relations (Cambridge, MA: Belknap Press, 2021), 64. 
how Sino-Korean relations were reconfigured before and after the Manchu takeover of China in the mid-seventeenth century.

As we seek to address such questions, we are fortunate to have the recent publication of three studies that show us the depth and complexities of Sino-Korean relations during the Qing period. The authors of these studies, Seonmin Kim, Nianshen Song, and Yuanchong Wang, closely analyze Chinese, Korean, and Manchu sources and examine separate yet interconnected aspects of the relationship between the Qing and the Chosŏn. Kim's analysis focuses on ginseng as a symbolic commodity for the Manchus and demonstrates the manner in which ginseng-and its gradual depletion-shaped the nature of the space along the Yalu River. Song's study, by contrast, takes us to the Tumen River area east of Mount Paektu, or Mount Changbai, and elucidates the curious intersections of immigration, nationalism, and international law from the late nineteenth through the early twentieth century. Wang's examination of what he calls the “Zongfan 宗藩 system" (rather than "tributary system") highlights the significance and lasting influence of political and diplomatic norms in Northeast Asia from the rise of the Manchus in the early seventeenth century to the fall of the Qing in 1911 (3-6). This review essay will first outline the three studies individually before discussing some of their overarching themes and the questions that they raise.

Kim's Ginseng and Borderland: Territorial Boundaries and Political Relations between Qing China and Chosŏn Korea, 1636-1912 examines the space between the Qing and the Chosorn by analyzing the significance of ginseng as a commercially and politically indispensable commodity in Manchuria. Access to ginseng, according to Kim, was intricately tied to the identity of the Manchu rulers and elite, and she situates Qing policy on ginseng in the framework of the tributary relationship between the Qing and the Chosŏn. She describes the key subject of her analysis as follows: "this book explores the territorial boundary between the Qing and the Chosŏn and the asymmetrical tributary relationship between the two states. It discusses the process by which the two countries recognized and managed their separate realms through an analysis of the Qing policy regarding Manchuria, the Qing-Chosŏn tributary relationship, and the two states' ideas about territory and sovereignty" (4). Building on recent debates in borderland studies, Kim assesses different phases of the change that transpired in the space between the Qing and the Chosŏn and characterizes them as a gradual transformation from "frontier" to "borderland," and then from "borderland" to "border."

In her succinct introduction, she explains these concepts in the following ways: A "frontier" is defined as "an undefined zone between distinct political or social entities, such as the Jurchen tribes and the Chosŏn or the Jurchens and the Ming, whose power relations were often asymmetrical, with one being more powerful and tending to extend its influence over the other," while a "borderland" "refers not to the concrete strip of land between the two countries but to the significance of this area as a zone of 
demarcation, a site at which the two neighbors encountered one another and clashed but nonetheless recognized their mutual boundary." A "border," then, is characterized as "a defined boundary between two neighboring powers, such as modern China and Korea, a product of the emergence of the nation-state with its attendant consciousness of sovereignty and territory" (15).

In five well-researched and chronologically arranged chapters, Kim scrupulously traces this transition through the lens of state control over ginseng in Manchuria from the late Ming to the late Qing period. Chapter one, titled "From Frontier to Borderland," focuses on the late Ming period and examines the intersection of "unclear frontiers" among the Ming, the Chosŏn, and the Jurchens. Drawn by the rising value of Liaodong ginseng in the sixteenth century, the Ming, the Chosŏn, and the Jurchens vied for greater control. While the trespassing of Han Chinese into Jurchen land for ginseng poaching caused friction between the Ming and the Jurchens, writes Kim, the Ming was also "wary of the possibility of Korean-Jurchen collaboration and the potential threat to Ming control over Liaodong" (29). Nurhaci's consolidation of competing Jurchen tribes and growing control over Liaodong in the late sixteenth century fundamentally shifted the balance of power in the region. Korean trespassing for ginseng poaching also continued, prompting Hong Taiji to issue a stern warning to the Chosŏn in 1633: "[All of these intruders] escaped your country and entered our territory. Only some of the cases have been reported to me. Who knows how many Koreans are trespassing on our land? You have broken your promise to us and let your people come into our land to collect ginseng and hunt animals. Your country is also full of animals, but were any of our people stealing into your land to get them?" (42) Kim stresses that "Hong Taiji considered ginseng not only a special resource growing in Jurchen territory but also a symbol of the Jurchens themselves. This view reinforced the idea that non-Jurchens should not be allowed access to it.” When King Injo's surrender to Hong Taiji in 1637 created a suzerain-vassal relationship between the Qing and the Chosŏn, ginseng was not among the items that the Qing demanded from the Chosorn as tribute. Kim notes that "the Manchus saw it as a product of Manchu lands and a symbol of the Manchu people" and that "not requesting Korean ginseng emphasized that the Manchus did not consider ginseng a local Korean product, a specialty of a vassal's domain" (44).

Hong Taiji's two invasions of Korea, however, failed to solve the issue of Korean trespassing into Liaodong. Chapter two, "Making the Borderland," brings us to the early Qing period and examines the 1712 mapping expedition to Mount Changbai by Mukedeng at the order of the Kangxi emperor. This famous expedition led to the erection of the so-called "Mukedeng stele," and Kim's analysis highlights three aspects of the investigation: the significance attached to cartographic expeditions in Qing empire building, consolidation of the ruling status of the Manchus, and the agency of the Koreans in the process of making this borderland. As Kim writes, "the northeastern region 
carried special meanings for the Qing imperial court" (52) as the birthplace of the Manchus and as a strategically crucial area bordering Russia, Mongolia, and Korea. The Qing rulers, therefore, considered solidifying claim and control over Manchuria to be of vital importance.

Such a sense of priority was expressed, for instance, by the three inspection tours to the Shengjing (Mukden) area that the Kangxi emperor conducted and the 1712 investigation of Mount Changbai. One of the goals of Mukedeng's mission was to clarify the Qing-Chosŏn boundary by locating the riverhead of the Tumen River. While Mukedeng did erect a stele marking the boundary, Chosŏn officials soon discovered that the stele was erected in the northeast of the actual riverhead, thus granting the Chosŏn additional territory. Fully aware that the erection of the stele actually worked to their benefit, the Koreans chose not to inform the Qing of their findings. But neither Mukedeng nor the Kangxi emperor ever attempted to verify the accuracy of the stele's location. For the Kangxi emperor, Mukedeng's investigation had already demonstrated the suzerain status of the Qing over the Chosŏn. In Kim's assessment, "[t]he presentation of imperial virtue and power, rather than the demarcation of clear territorial boundaries, was the important issue" (70). Thus, what resulted from Mukedeng's investigation was a borderland where the claims of Qing superiority and the strengthened notion of Chosŏn territorial sovereignty could coexist. As long as the tributary relationship between the two courts remained intact, both sides could find gains in this borderland without calling Mukedeng's achievements into question.

Chapters three and four, titled "Managing the Borderland" and "Movement of People and Money," discuss the manner in which the Qing state sought to tighten its monopoly over ginseng in Manchuria and highlight the decisions the Yongzheng and Qianlong emperors made for the purpose of maintaining an uninhabited zone between Qing and Chosŏn territory. This "uninhabited zone" over time became commercialized and ironically attracted profit seekers, in large part due to the near constant flows of envoys and their entourages traveling on tribute missions. In 1745, the Qianlong emperor established three Ginseng Offices in Shengjing, Jilin, and Ningguta in order to directly control the collection of ginseng and to curb illegal poaching. Alarmed by the persistence of trespassing and illegal poaching of ginseng, the Shengjing military governor also proposed to the Yongzheng emperor that a military post be established on a sandbank in the upstream stretch of the Yalu River to conduct stricter patrol. But in the end the proposal was not implemented. "By highlighting the inferior status of the Chosŏn vis-à-vis the great Qing," notes Kim, "the Koreans succeeded in preventing the construction of a Qing military facility on the Yalu River" (78-79). This asymmetrical relationship allowed the Qing-Chosŏn borderland to become "a zone of demarcation" rather than a "concrete strip of land."

Finally, in chapter five, titled "From Borderland to Border," Kim demonstrates that 
the changing regional and international environment of the late nineteenth century demanded that the "exact limits of their territories" (130) be established. A crucial factor in this development, according to Kim, was the depletion of natural resources in Manchuria and-most importantly and symbolically—-the gradual disappearance of ginseng stocks. The number of ginseng permits that the Qing court issued declined from 6,000 in 1760 to a mere 632 in 1852 (132). In Kim's analysis, the dwindling supply of ginseng weakened the very reason for Qing restrictions on entry into Manchuria and led to an influx of Chinese settlers into the region. Abandoning its initial policy of Manchu monopoly in Manchuria, the Qing court eventually adopted a policy of "recruiting civilians to populate, cultivate, and settle" (yimin shibian 移民實邊) the region (130). The swiftly changing geopolitical situation surrounding both the Qing and the Chosŏn in the late nineteenth century was another factor that transformed the Qing-Chosŏn boundary from "borderland" to "border." Moreover, as a growing number of Koreans settled in the areas north of the Tumen River, the question of jurisdiction over them became a thorny diplomatic issue between the two courts, and they conducted joint surveys of the boundary in 1885 and 1887 in an attempt once again to clarify the location of the Tumen riverhead. The joint surveys of the 1880s did not fully resolve the issue of the Tumen riverhead or, by extension, the question of how and where the Qing-Chosorn boundary ought to be drawn. Yet the underlying principles and norms of the tributary relationship between the Qing and the Chosŏn were also showing signs of imminent change in this period. Kim concludes: "The Qing empire and the Chosŏn kingdom could tolerate the existence of a borderland, but modern China and Korea needed a clear border between them" (150). In this manner the transformation of the Qing-Chosŏn borderland to a territorial border became complete.

In Making Borders in Modern East Asia: The Tumen River Demarcation, 1881-1919, Nianshen Song begins with the story of the Mukedeng stele, which was installed following his 1712 investigation and mysteriously disappeared in July 1931. In terms of a temporal focus, Song's study concentrates on the four decades from 1881, when "the Tumen River region was about to become a knot within a sophisticated nexus composed of multilateral and multilayered power interactions" (53), to 1919, when demonstrations against Japanese colonial rule over Korea spread across the Korean peninsula to Yanbian, which is located in the east of today's Jilin province in China. As we have seen above, one of the contentious questions in the Tumen River dispute concerned Korean settlers, or "Korean squatters," on the northern bank of the Tumen River. A series of natural disasters in the northeastern province of Hamgyŏng in the 1860s and 1870s forced many Koreans to cross the Tumen River into Qing territory. Many such refugees eventually returned to Korea once the initial impact of the disasters subsided. However, as the Qing began encouraging civilian settlement in Jilin for agricultural development, a growing number of Koreans resettled in the north of the Tumen River, 
often with the explicit permission of Korean local officials in Hamgyŏng. Song states: "border trespassing was occurring on an unprecedented scale in 1881" (16).

The six chapters of Song's study analyze key dimensions of this dispute, due to which the Qing and Chosŏn courts later launched joint investigations of the Qing-Chosŏn boundary in the late 1880s. Chapter one examines the relationship between the state and people in the Tumen River region and state control, or lack thereof, over Korean "squatters" in Yanbian, who crossed the Tumen River over to the Qing side and settled down. Song shows that Qing officials initially drew a distinction between smuggling, poaching, and logging, the latter two of which were deemed "subsistence efforts" made necessary due to harsh living conditions in northeastern Korea, and treated Koreans in Yanbian with words of compassion in the framework of tributary relations between the Qing and the Chosŏn. The office of the vice-commander-in-chief of Hunchun ordered in 1881, for example: "[We recently found Korean people who had] sneaked across the border river and went to our villages to exchange goods privately. Though going against the law, those foolish vagrants were forced by poverty ... When encountering Korean crossers, you should politely persuade them to return and not bully them" (31).

In chapter two, Song analyzes state responses to the "squatter problem" and the joint investigations the Qing and the Chosŏn conducted in 1885 and 1887, especially focusing on two local officials, Yi Chung-ha 李重夏 (1846-1917) of the Chosŏn and Wu Dacheng 吳大澂 (1835-1902) of the Qing, who were charged with the task of leading the joint investigations. Despite their efforts towards the "territorialization" (92) of the Tumen River region, however, the Qing and the Chosŏn were unable to agree on a mutually acceptable boundary between their territory. In chapter three, the author shifts his focus "from space to people" (102) and examines the Korean emigrants who resettled in the area to the north of the Tumen River. This area came to be known as "Kando" 間島 in Korean (Ch. Jiandao, J. Kantō), which literally means "in-between island." Drawing on Japanese, Manchu, Chinese, and Korean sources, Song analyzes the emergence of this space from multiple perspectives, especially the growing influence of bandits, which he calls the "non-governmental armed force" (121) of the Kando region.

Chapter four, titled "Taming the Frontier: Statecraft and International Law," discusses central legal questions that emerged out of the formation of the space of Kando: What nationality, if any, did the Korean emigrants in Kando hold? Did they remain Chosŏn subjects? Or did they become Qing subjects when they resettled in the area north of the Tumen River? Song demonstrates that this process represented a fundamental conflict between Zongfan (or "tributary") ideology and international law at the turn of the twentieth century. He writes: "In their struggle a new discursive regime in the form of international law gradually overcame, if not completely replaced, the zongfan ideology. Along with this change, the geographical and political meanings of this multilateral frontier were significantly transformed" (128-29). 
In chapter five, titled "Boundary Redefined: A Multilayered Competition," Song explores the escalating competition among empires in the Tumen River region and the Sino-Japanese demarcation of 1907-9. When compared to the joint investigation of the region the Qing and the Chosŏn conducted, negotiations during this period exhibited crucially different characteristics: "It was no longer a contest of dynastic geography," writes Song. "Although geography was still a battlefield in the diplomatic struggle, it provided no more than an intellectual context for intensive political negotiation. Neither side raised any new evidence from the topographical perspective, nor was there a joint investigation in the field. The real confrontation here, as mentioned, was over state building in a society composed mainly of the immigrants from a third country" (172). To underscore "the close alliance between knowledge and politics, as well as the intellectual symbiosis of nationalism and colonialism" (201) in the boundary dispute, Song discusses writings of Naitō Konan 內藤湖南 (1866-1934), Song Jiaoren 宋教仁 (1882-1913), and Sin Ch'ae-ho 申采浩 (1880-1936), three intellectuals from Japan, China, and Korea. Song also demonstrates the complex relationships among state and non-state actors. In his analysis, "The power structure in the Tumen demarcation was thus entangled in multiple layers, with various agents woven into the nexus of interlaced tensions and coalitions" (172).

In September 1909, the Chinese and Japanese governments signed the Jiandao/ Kantō Convention, which determined that the Tumen River was the boundary between China and Korea. While the Convention was touted as a diplomatic success by the Japanese, it never fully resolved the question of nationality and identity for the Koreans living in the Tumen River region. In the final chapter, titled "People Redefined: Identity Politics in Yanbian," Song analyzes this question of nationality and identity in the immediate aftermath of "several watershed events" (221), including the assassination of Itō Hirobumi 伊藤博文 (1841-1909) by An Chung-gŭn 安重根 (1879-1910) in October 1909, Japan's annexation of Korea in August 1910, and the abdication of the last Qing emperor in February 1912. There emerged out of this geopolitical context "a new spatial concept" (222) of Yanbian, referring to the four counties of Yanji, Helong, Wangqing, and Hunchun on the north bank of the Tumen River, which were home to a high concentration of Korean immigrants. The number of Koreans residing in Yanbian rapidly increased, especially after the Japanese annexation. According to Japanese census data, the Korean population in Yanbian grew nearly threefold from 109,500 in 1910 to 297,150 in 1919 (222). After 1910, Japan considered Koreans in Yanbian to be "Japanese subjects." Song's study shows a complex web of economic interests, national identities, and political allegiances. The question of jurisdictional authority over the Koreans in Yanbian further added to their ambiguous political and social status in the second decade of the twentieth century. All in all, Song stresses that "boundaries for both territories and people are relative rather than absolute, flexible rather than rigid" 
(269). His meticulous analysis richly elucidates this "polyphonic" nature of boundary making.

As we try to make sense of the processes of boundary making along the Yalu and Tumen Rivers, Yuanchong Wang's Remaking the Chinese Empire: Manchu-Korean Relations, 1616-1911 offers a helpful analytical framework. The author draws a distinction between Qing-Chosŏn relations and the earlier relationship between the Ming and the Chosŏn and underscores the special role that the Chosŏn played in the transformation of China into a modern state. He explains: "I avoid enshrining the Qing-Chosŏn relationship in the pantheon of Chinese narratives of Sino-Korean relations since the Western Zhou, and I refrain from conflating the Qing-Chosŏn relationship with that between the Ming and Chosŏn. Rather, I explore the unique and crucial role of these bonds in providing the Qing with the political, intellectual, and ideological sources with which it reconstructed itself and the Chinese empire and eventually gave birth to a modern Chinese state" (6). Wang in particular points out the continuing influences of two approaches to the question of assessing the "imperialist" characteristics of the Qing: "High Qing imperialism" and "Late Qing imperialism." The former stresses the significance of Qing expansionist tendencies toward Inner Asia especially in the eighteenth century, while the latter sees Qing policy toward Chosŏn Korea in the late nineteenth century as a manifestation of imperialist intent and capability. Wang writes, however, that neither approach offers an adequate explanation, for both approaches risk adopting "Eurocentric narratives of imperialism" (17). Instead, Wang proposes a perspective of what he calls "Zongfanism." "What I call 'Zongfanism' in this book," writes Wang, "can provide us with a different perspective for observing the rise and fall of the Eurasian Chinese empire under the Qing Dynasty and the rise of modern sovereign states in China and its neighboring countries. Zongfanism refers to a Chinese system of political and diplomatic communication conducted between, on the one hand, a political entity that culturally identified itself as the exclusive civilized center of the world, and, on the other hand, the political entities on its periphery that the center considered less civilized or even barbarian" (18).

In six chronologically arranged chapters, which are grouped into two parts, Wang describes the complex-and particularly violent, in the earlier stages-interactions between the Qing and the Chosŏn. The Manchu invasions of the Chosŏn and the subsequent Chosŏn surrender occurred during the relatively early stages of the Jin/Qing state formation, and the incorporation of the Chosŏn into the Qing worldview proved crucial in "the process of recentering the Middle Kingdom undertaken by the Qing" (50). Wang writes: "In short, the Qing-Chosonn relationship was the seedbed of the Qing's entire Zongfan arrangement, from which the political legitimacy of both sidesthe Qing and its outer fan-sprang" (60). In seeing the Qing-Chosŏn relationship as a "seedbed," rather than as a unique example, Wang emphasizes not only the tran- 
sregional applicability of the "Chosŏn model" to Qing policy in general, but also its centrality in the building of political and diplomatic relationships with the neighboring polities and the world. This model came under considerable external pressure in the mid-nineteenth century, when the Opium Wars and the treaties signed with Western powers, especially the Sino-British treaty of 1858, "marked the beginning of the collapse of the centuries-long ritual system and the erosion of the Zongfan infrastructure" (112). Yet, this diplomatic infrastructure did not disappear overnight, according to Wang, since "the disintegration of Sinocentrism as a result of the 1858 treaties occurred on the Qing's intellectual periphery, not at the core of its intellectual and ideological structure as informed and represented by the Qing's principal outer fan" (113).

In the latter three chapters of the book, Wang shows us in great detail how the geopolitical developments of the late nineteenth century severely tested the foundation of the Zongfan infrastructure. Chapter four, titled "Defining Chosŏn," probes the tension and misunderstanding which emerged in the geopolitical environment of late nineteenth-century East Asia. In 1866 and 1871, France and the US launched separate military expeditions against the Chosonn in retaliation for the persecution of French Catholic missionaries in the case of France, and for the killing of the crew of the schooner General Sherman in the case of the US. In both incidents, the Qing court became involved as both French and American officials understood that the Qing held a suzerain status over the Chosŏn in the Sino-Korean relationship. "Both China and Chosŏn declared," Wang writes, "that Chosŏn was China's subordinate country with the right of autonomy; the Western countries and Japan interpreted this to mean that Korea was an independent sovereign state with all international rights" (124). The Zongli Yamen 總 理衙門, a Qing foreign office established in 1861 in the aftermath of the Second Opium War, claimed in response to diplomatic inquiries that the "Chosŏn, as a shuguo [subordinate country] of China, only uses the Chinese calendar, uses Chinese regnal titles, and pays annual tribute to China" (123). But this relationship did not demand, according to the Zongli Yamen, that it would intervene in the Chosŏn court's handling of its own affairs, including the disputes with France and the US. Such an explanation caused "confusion," according to Wang, and this confusion was due in part to translation. When the Zongli Yamen published a Chinese translation of Henry Wheaton's Elements of International Law in 1864, many English legal terms were translated using existing Chinese tributary concepts. For example, the term colony was rendered as pingfan 屏藩 “fence" or shuguo 屬國 “subordinate country." The published translation, Wanguo gongfa 萬國 公法 ("Public Law of All Nations"), ${ }^{4}$ served as an essential guide to international law. But "China's perspective remained essentially familistic, whereas the European and the Americans operated in a primarily legal context" (124). The resulting confusion was

4. This translation of Wanguo gongfa follows that of Immanuel C. Y. Hsü, China's Entrance into the Family of Nations: The Diplomatic Phase, 1858-1880 (Cambridge, MA: Harvard University Press, 1960), 129. 
such that "Since the 1860s, the terminological inconsistency led to great confusion over the nature of the Zongfan relationship and growing conflicts between China, Korea, and other countries" (124). This inconsistency also became a focal point in the SinoJapanese negotiations in early 1876 over the status of Korea. Led by Li Hongzhang 李 鴻章 (1823-1901), who was shaping Qing foreign policy as governor-general of Zhili, and Mori Arinori 森有禮 (1847-1889), the Japanese minister plenipotentiary, the negotiations were held in Baoding and conducted mostly in English as the Japanese sought to conclude the Kanghwa Treaty with the Chosŏn with the threat of military force. The negotiations in the end did not produce a shared understanding over the status of Korea. But when the Kanghwa Treay was signed in late February 1876, written in Chinese and Japanese, its first article stated that Korea was a country with the right of selfrule (zizhu zhi bang 自主之邦). But its English translation, which the Japanese Foreign Ministry prepared, rendered the phrase as "an independent state" (142).

The brief yet politically tense period between 1877 and 1884 is the focus of chapter five. Wang characterizes this period as one in which "A pair of coexisting and correlated dual diplomatic networks developed between China and Chosŏn" (144). What the author calls the "outer network" comprised the traditional Zongfan framework into which new treaty-based relations with Western nations and Japan were integrated. The "inner network," by contrast, "comprised, first, the conventional system of court-tocourt interactions between the imperial court in Beijing and the royal court in Seoul, and, second, the newly founded state-to-state system between China and Chosŏn" (14445). As the Qing increasingly asserted its suzerain status over the Chosŏn in the changing geopolitical environment of the late nineteenth century, the ambivalence and awkwardness of these dual networks became apparent. Products of bilateral negotiations over trade took the form of regulations (zhangcheng 章程) rather than treaties. When a mutiny threatened the stability of the political order in Korea and raised the likelihood of increased Japanese influence in 1882, the Qing intervened militarily, which, according to the author, served "as a public presentation of the underlying nature of the supreme and patriarchal power the Qing had wielded over its subordinate country since 1637" (160).

The final chapter, titled "Losing Chosŏn," examines the Sino-Korean relationship in the period between 1885 and 1911. In the aftermath of an attempted coup in late 1884, the Qing appointed Yuan Shikai 袁世凱 (1859-1916), a protégé of Li Hongzhang, as the "imperial resident in Chosŏn in charge of diplomatic and commercial intercourse" (Qinming zhuzha Chaoxian zongli jiaoshe tongshang shiyi 欽命駐紮朝鮮總 理交涉通商事宜), and Yuan exerted tremendous influence over the Chosŏn court and King Kojong (r. 1864-1907) himself. "When Korean officials expressed concern over the breadth of Yuan's power in the country," Wang writes, "Yuan clarified that his aim was simply to 'justify the orthodox legitimacy of Chosŏn's status as China's subordinate 
country"' (180). During this period, Qing officials also discussed the merits and necessity of administratively integrating Korea as a province. Xinjiang and Taiwan were converted into provinces in 1884 and 1885, respectively. But the Qing in the end did not annex Korea, which, according to the author, "could have led to a domino effect in China's borderland in Manchuria, Xinjiang, Tibet, and Yunnan, where China was contending with Japan, Russia, Britain, and France" (184). Meanwhile, a growing number of Chosŏn officials began openly expressing nationalistic aspirations and rejecting the subordinate status of the Chosŏn to the Qing. It created a political situation which the Japanese sought to exploit to their advantage. The Qing defeat in the Sino-Japanese War of 1894-95 and the subsequent signing of the Treaty of Shimonoseki structurally realigned the Sino-Korean relationship. The treaty, written in Chinese, Japanese, and English, declared the "full and complete independence and autonomy" of Korea from China. In a symbolic sense, this "loss" of Korea became visualized in Seoul in the construction of the Gate of Independence and the burying of the Samjondo stele, which commemorated the Chosŏn surrender to the Qing in 1637. In interesting ways, however, this transformation was neither immediate nor complete at the provincial level. As late as May 1901, six years after the signing of the Treaty of Shimonoseki, the governor of Zhejiang handled the shipwreck of a Korean fishing boat, explicitly citing the conventional norms of "cherishing the men from afar." "In provincial practice," Wang writes, "Zongfan norms were no weaker than they had been in the seventeenth and eighteenth centuries" (210).

Both individually and collectively, the three studies examined in this review point to a transformation in Qing-Chosŏn relations from the late nineteenth to the early twentieth century. Kim's study describes a transformation of a borderland to a border. Song in his analysis of the Tumen River dispute narrates a transformation of geographical and national consciousness. Wang's examination of the Zongfan system underscores a transformation of political and diplomatic norms in modern East Asia. These changes were driven and conditioned in turn by transformations of ecological, societal, and geopolitical conditions in the region. In compelling ways, the three studies show us the manner in which change in those conditions in the late nineteenth century-be it the depletion of ginseng stocks in Manchuria, the formation of Korean migrant communities on the northern bank of the Tumen River, or the escalation of political and military pressure exerted by the West and Japan-triggered a series of repercussions which ultimately altered the ways in which Qing China and Chosŏn Korea engaged with each other.

At the same time, the three studies also raise new and complicated questions about the nature of the transformative changes that they depict. We can further ask, for example, about the regionally specific configuration of the "modern international order" (Kim, 17) in East Asia and about the extent to which this modern international order 
and the tributary relationship between the Qing and the Chosŏn intersected from the late nineteenth to the early twentieth century. Pointing to one such intersection of traditional and modern conventions, Wang describes the elaborate ritual ceremonies the Chosŏn court held in Inch'ŏn and Seoul in November 1890 in honor of arriving Qing envoys. "Rituals," Wang notes, "were deeply involved in the tortuous transformation of both China and Korea from parts of the empire to modern sovereign states" (196). Similarly, addressing the interlinked nature of the formation of modern states in East Asia, Song writes: "The intertwined nation makings in China, Japan, and Korea significantly shaped the East Asian world order; an international relation was transformed out of, rather than replaced, the zongfan hierarchy" (268). One question that begs further examination, then, is how the rituals of the tributary relationship between the Qing and the Chosŏn shaped the modern sovereign states that China and Korea became. If we distinguish between Ming-Chosŏn and Qing-Chosŏn relations, as Wang has emphasized, we need to ask in more detail how the Manchus and their political, cultural, and ethnic consciousness shaped the modern and East Asian world order. The three studies point to many other areas of further research, including the roles of translation, technology, and the environment in directing the transformations of the Qing-Chosorn tributary relationship.

In her analysis of the Yongzheng emperor's 1728 edict on an incident of illegal ginseng poaching and bribery on the western bank of the Yalu River, Kim writes: "Seen from the northeastern periphery, the Chosonn was a foreign country, but from the perspective of the center the same neighbor was regarded as a tributary state" (87). This coexistence of different yet interrelated functions that the Chosŏn fulfilled-often proactively - was inseparable from the spatial, political, and cultural conceptions that the three studies vividly illustrate. What they also demonstrate is the delicate balance that Qing and Chosorn officials, both at state and local levels, sought to maintain in responding to cases of illegal poaching, squatting, or protocol violations throughout the Qing period. How or whether the significance of maintaining that balance became lost is a question that resonates beyond the Qing period. 